\title{
Immunological Status to Hepatitis B Virus of Pregnant Women in Dakar, Senegal
}

\author{
Maguette Sylla Niang ${ }^{1,2^{*}}$, Khadidiatou Sarr Fall2, Babacar Mbengue ${ }^{1}$, Moustapha Mbow ${ }^{1}$, \\ Ndiokhor Nd. Diouf', Ousseynou Boye ${ }^{2}$, Gora Lo ${ }^{3}$, Papa Madieye Guèye ${ }^{3}$, Rena Derwiche ${ }^{1,2}$, \\ Amina Sow Sall ${ }^{3}$, Tandakha Ndiaye Dieye ${ }^{1}$, Alioune Dieye ${ }^{1}$ \\ ${ }^{1}$ Service of Immunology, Faculty of Medicine, Pharmacy and Odontology (FMPO), Cheikh Anta Diop University of Dakar \\ (UCAD), Dakar, Senegal \\ ${ }^{2}$ Laboratory of Medical Biology, General Hospital of Grand-Yoff, Dakar, Senegal \\ ${ }^{3}$ Department of Biological and Pharmaceutical Applied Sciences, Pharmacy and Odontology (FMPO), Cheikh Anta Diop \\ University of Dakar (UCAD), Dakar, Senegal \\ Email:*immunologiefmpos@gmail.com
}

How to cite this paper: Niang, M.S., Fall, K.S., Mbengue, B., Mbow, M., Diouf, N.Nd., Boye, O., Lo, G., Guèye, P.M., Derwiche, R., Sall, A.S., Dieye, T.N. and Dieye, A. (2017) Immunological Status to Hepatitis B Virus of Pregnant Women in Dakar, Senegal. Open Journal of Immunology, 7, 37-44. https://doi.org/10.4236/oji.2017.72003

Received: June 6, 2017

Accepted: June 27, 2017

Published: June 30, 2017

Copyright $\odot 2017$ by authors and Scientific Research Publishing Inc. This work is licensed under the Creative Commons Attribution International License (CC BY 4.0).

http://creativecommons.org/licenses/by/4.0/

\begin{abstract}
Objective: Evaluate the immunological status to hepatitis B virus of Senegalese pregnant women by screening HBs antigen. Material and methods: The selection criteria of women were presence at the laboratory for biological exams of pregnancy follow-up. All volunteers for the study were screened for $\mathrm{HBs}$ antigen ( $\mathrm{HBs} \mathrm{Ag}$ ). Investigation of chronic hepatitis B markers ( $\mathrm{HBe} \mathrm{Ag}$, anti-HBe, viral quantification) was performed in $\mathrm{HBs}$ Ag positive participants. The concentration of anti-HBs antibodies was assessed in HBs Ag negative women. Results: One hundred and fifteen (115) pregnant women were included in the study from July to October 2014 . The mean age was $29 \pm 6$ years, ranging from 16 to 47 . The seroprevalence of $\mathrm{HBs} \mathrm{Ag}$ was $12 \%$ and the majority of women $(90 \%)$ were not vaccinated. Any of the $14 \mathrm{HBs}$ Ag-positive subjects did not express serum $\mathrm{HBe} \mathrm{Ag}$, (marker of active viral replication) and all were positive for anti-HBe antibodies. Their viral load (HBV DNA) was undetectable and serum transaminases were normal. The anti-HBs antibodies titrated in HBs-Ag negative women serum revealed that only 46 had protective levels against $\mathrm{HBV}$ whilst 55 of them were unprotected.
\end{abstract}

\section{Keywords \\ HBs Ag, Pregnancy, Senegal}

\section{Introduction}

Hepatitis B is a major public health problems, represents potentially mortal hepatic infection. About 257 million people suffer from chronic infection with the 
hepatitis B virus defined as positivity for the $\mathrm{HBs}$ antigen ( $\mathrm{HBs} \mathrm{Ag}$ ) for at least 6 months. In 2015, 887,000 people died from cirrhosis or liver cancer deriving from hepatitis B infection. Africa has the heavier burden with a prevalence of over $6.1 \%$ in adults. The vaccine against hepatitis B, available since 1982, is effective at $95 \%$ in preventing the infection, development of chronic hepatitis and liver cancer [1]. The vertical transmission of the hepatitis B virus remains a major cause of the maintenance of the hepatitis B epidemic in the world [2].

As a matter of fact, the risk of transmission to the newborn is high when the mother is HBs Ag positive and the risk of passage to the chronicity of the contaminated newborn is also high. Therefore, investigation of HBs Ag must be carried out in all the pregnant women [3]. Senegal is a highly endemic area for viral hepatitis and especially of hepatitis B. As consequence of such high prevalence, $85 \%$ of the Senegalese population has at least one marker of the hepatitis B virus (HBV) [4] [5]. Despite implementation of hepatitis B national program since 1999 to fight against the infection, there are few efforts to evaluate efficacy of implemented policies. In this context, we decided to investigate the prevalence of HBs Ag in a population of pregnant women in Dakar and assess risk transmission from mother to child through the level HBe antigen ( $\mathrm{HBe} \mathrm{Ag}$ ).

\section{Materials and Methods}

The study is an exploratory, descriptive, and analytical spanned over 4 months, from July to October 2014, at the Medical Biology Laboratory (MBL) of the General Hospital of Grand-Yoff (HOGGY) in Dakar, Senegal.

\subsection{Study Population}

The selection criteria of the women were their presence at the laboratory for their biological follow up.

\subsection{Data Collection}

A questionnaire was administered to collect data related to the socio-demographic characteristics (matrimonial situation, profession, geographic origin, place of residence), the stage of the pregnancy, the number of former pregnancies, the number of children, the serologic status with respect to the HBV, notion of previous vaccination against the HBV, family history of jaundice and hepatitis, history of surgery, gynaecological antecedents (IVG, abortions) and risk factors such as scarifications, tattoos, and transfusions. Data were electronically recorded using the Microsoft Office Excel version 2007.

\subsection{Biological Tests}

HBs Ag was screened in all study participants by immunochromatography (Determine TM HBs Ag Alere, USA). Analysis of the HBe Ag and anti-HBe antibodies, markers of chronic hepatitis $B$ ( $\mathrm{HBe} \mathrm{Ag}$, anti $\mathrm{HBe}$ ), was carried out in the HBs-Ag positive pregnant women by chimiluminescence using Cobas e411 (Roche Diagnostics, France) and viral DNA was assessed by real time PCR using 
Real Time (m2000, Abbott Diagnostics, USA). The anti-HBs antibodies were measured in HBs Ag negative women using a microparticular immunological technique by chimiluminescence with Architect i1000 (Abbott Laboratories, USA). The prevalence was defined by reporting the number of HBs Ag-positive women to the total population.

\subsection{Data Analysis}

Data was exported and analyzed using Statview ${ }^{\circledast} 5.1$ (SAS Institute Inc. Version 5.0). The degree of dependence between the risk factors and the presence of HBs Ag was evaluated. A p-value below 0.05 was considered statistically significant. The risk factors with a p-value $<0.05$ were considered as associated with the presence of HBs Ag. Level of dependence between qualitative variables was calculated using the odds ratio.

\subsection{Ethical Aspects}

The study was conducted in concordance with the ethical principles of the Declaration of Helsinki. All volunteers provided informed consent.

\section{Results}

\subsection{Characteristics of the Study Population}

A hundred and fifteen pregnant women were included in the study from July to October, 2014. Their age average was of $29 \pm 6$ years with the extremes going from 16 to 47 years.

Thirty eight percent of the patients were jobless and the majority (98\%) was married. The average stage of the ongoing pregnancy was $4 \pm 1.7$ months with a range of 1 to 8 months. The average number of children per woman was 1.16 with extremes from 0 to 7 children. Table 1 describes in detail these characteristics.

\subsection{HBV Serological Status}

The majority of the pregnant women $(n=98)$ declared that they were not vaccinated against hepatitis $\mathrm{B}$ while $10 \%(\mathrm{n}=11)$ were. The other ignores their vaccination status.

\subsection{HBs Ag Prevalence}

HBs Ag was positive in 14 out of 115 pregnant women, representing a prevalence of $12 \%$ (Figure 1).

\subsection{Risk Factors of HBV Infection}

We did not find significant relationship between the risk factors and the presence of HBs Ag (Table 2).

\subsection{Markers of Chronic Hepatitis B}

Among the HBs Ag positive patients $(\mathrm{n}=14)$, any of them did not express serum $\mathrm{HBe} \mathrm{Ag}$ characteristic of active multiplication. Moreover, all of them 
Table 1. Demographic characteristics of pregnant women.

\begin{tabular}{|c|c|c|c|}
\hline \multicolumn{2}{|c|}{ Characteristics } & \multirow[t]{2}{*}{ Number (n) } & \multirow[t]{2}{*}{ Percentage (\%) } \\
\hline Age (year) & & & \\
\hline & $<20$ & 3 & 3 \\
\hline & $20-29$ & 61 & 53 \\
\hline & $30-39$ & 41 & 36 \\
\hline & $40-47$ & 9 & 8 \\
\hline \multicolumn{4}{|l|}{ Employment } \\
\hline & Unemployed & 44 & 38 \\
\hline & Employed & 48 & 42 \\
\hline & Student & 23 & 20 \\
\hline \multicolumn{4}{|l|}{ Marital status } \\
\hline & Unmarried & 2 & 2 \\
\hline & Monogamy & 60 & 52 \\
\hline & Polygamy & 53 & 46 \\
\hline \multicolumn{4}{|l|}{ Gestational age } \\
\hline & First trimester & 43 & 37 \\
\hline & Second trimester & 62 & 54 \\
\hline & Third trimester & 10 & 9 \\
\hline \multicolumn{4}{|l|}{ Parity $(\mathrm{n}=114)$} \\
\hline & Primipara & 38 & 33 \\
\hline & Multipara & 57 & 50 \\
\hline & Bigmultipara & 19 & 17 \\
\hline
\end{tabular}

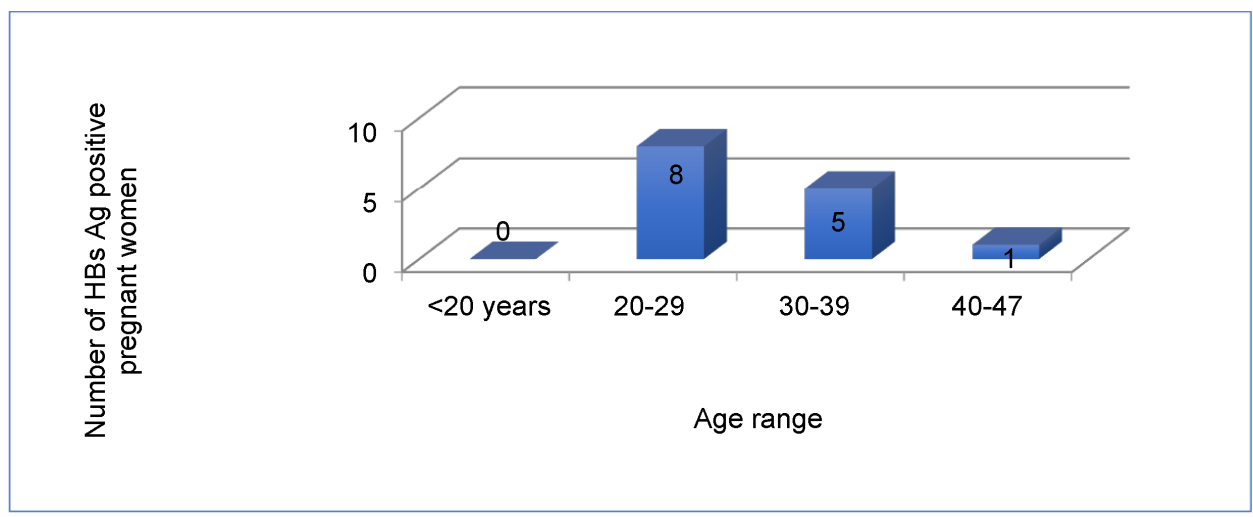

Figure 1. Prevalence of HBV Ag. This figure illustrates the frequency of HBS Ag positive pregnancy women according the age group they belong.

were positive for anti-HBe antibodies. Their viral load (HBV DNA) was undetectable. The alanine amino transferase (ALT) and aspartate amino transferase (AST) in the serum were normal.

\subsection{HBV Immunization}

Table 3 summarizes the characteristics of the pregnant women according to 
their serologic status with respect to the HBV.

We screened and titrated the anti-HBs antibodies in HBs Ag negative women. Among them, 46 had protective immunity against the HBV, with antibody concentrations above $10 \mathrm{mUI} / \mathrm{ml}$ while 55 were not protected (without antibodies) against the virus; fifty-one women ignored their vaccination status. Figure 2 shows the characteristic of the study population according the serological status.

Table 2. Risk factors of HBV infection among pregnant women (95\% CI).

\begin{tabular}{|c|c|c|c|c|c|c|}
\hline & \multicolumn{2}{|c|}{$\mathrm{HBs} \mathrm{Ag}$ positive women } & \multicolumn{2}{|c|}{ HBs Ag negative women } & \multirow{2}{*}{ Odds ratio } & \multirow[t]{2}{*}{$\mathbf{P}$} \\
\hline & Number (n) & Percentage (\%) & Number (n) & Percentage (\%) & & \\
\hline History of surgery & 3 & 21.4 & 10 & 9.9 & 2.48 & 0.21 \\
\hline History of blood transfusion & 0 & 0 & 1 & 0.09 & 1.28 & 0.61 \\
\hline Tattoos & 3 & 21.4 & 28 & 27.7 & 0.71 & 0.62 \\
\hline Scarifications & 0 & 0 & 8 & 7.9 & 0.37 & 0.5 \\
\hline Total of women tested & 14 & 100 & 101 & 100 & & \\
\hline
\end{tabular}

Table 3. Characteristics of pregnant women according to their HBV serological status.

\begin{tabular}{|c|c|c|c|c|c|}
\hline & HBs Ag positive & $\mathrm{HBe} \mathrm{Ag}$ negative & Anti $\mathrm{HBe}$ positive & $\begin{array}{l}\text { HBS Ag negative/ } \\
\text { anti-HBs negative }\end{array}$ & $\begin{array}{l}\text { HBs negative/ } \\
\text { anti-HBs positive }\end{array}$ \\
\hline $\begin{array}{c}\text { Number } \\
(\text { Total number }=115)\end{array}$ & 14 & 14 & 14 & 55 & 46 \\
\hline \multicolumn{6}{|l|}{ Age (years) } \\
\hline Mean & 29 & 30 & 30 & 29 & 28 \\
\hline Median & 28 & 29 & 29 & 28 & 28 \\
\hline Ranges & $16-47$ & $20-41$ & $20-41$ & $16-47$ & $16-40$ \\
\hline \multicolumn{6}{|l|}{ ADN VHB } \\
\hline $\begin{array}{l}\text { Ranges } \\
\text { (copy/ml) }\end{array}$ & $\begin{array}{c}0-202 \\
\text { undetectable }\end{array}$ & $\begin{array}{c}0-202 \\
\text { undetectable }\end{array}$ & $\begin{array}{c}0-202 \\
\text { undetectable }\end{array}$ & - & - \\
\hline
\end{tabular}

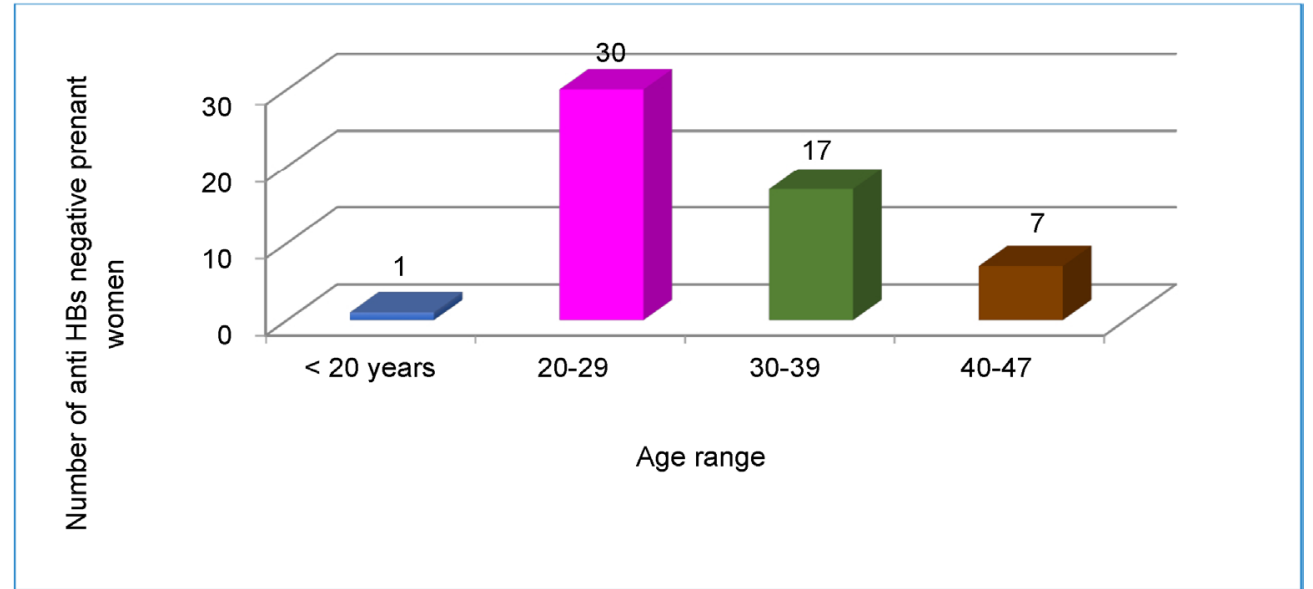

Figure 2. Frequencies of HBs negative women. From the 55 pregnant women protected against the hepatitis $\mathrm{B}$, the frequency of antibody anti-HBs negative participants are shown for each age range $<$ 20 years, [20 - 29], [30 - 39] and [40 - 47]. Their average age was of 29 years with extremes of 16 and 47 years. 


\section{Discussion}

The hepatitis B virus infection is a major public health problem in sub-Saharan Africa. A large proportion of infection has been conducted through vertical mother-child transmission and horizontal transmission in early childhood. The HBs antigen is used as biomarker to diagnosis the infectious at its chronic and acute stages. That is why we aim to evaluate the prevalence of HBs Ag in a population of pregnant women to gather essential information in the fight against HBV infections. Overall, there are variations in the prevalence of HBs antigen worldwide with 9.9\% in Picardie (France) [6], 2.1\% in Turkey [7], 3\% and 4\% in Tunisia [8] [9] [10], 8.26\% in Benin [11], 15.5\% in Mali [12].

Our study highlighted a prevalence of HBs Ag of $12 \%$ in pregnancy women, which is similar to those published in 2012 by the National Program of Fight against Hepatitis of Senegal which found a prevalence of HBs Ag of 11.7\%. Similar trends were also found in Dakar in 1993 [13] and in 2012 [14] by other teams, supporting pregnant women as reservoir of HBV infection.

All the $14 \mathrm{HBs}$ Ag positive women were unaware of their HBV serologic status, suggesting ignorance of the HBV infection in pregnant women.

Systematic screening however constitutes one of the most important tools to prevent the mother-child transmission of the HBV. The absence of a screening for the HBV infection before marriage supports the transmission ( 5 women were in a polygamous household), which increases the sexual transmission risk currently considered as the major mode of transmission of the $\mathrm{HBV}$ in countries where the transfusion is secure.

$\mathrm{HBe} \mathrm{Ag}$, characterizing active replication, was assessed for $\mathrm{HBs} \mathrm{Ag}$ positive pregnant women. None of them expressed HBe Ag, and all were anti-HBe antibodies positive. Those anti-HBe antibodies, characterising the end of viral replication, were found in all $\mathrm{HBs} \mathrm{Ag}$ positive women.

Their viral load, used to monitor the viral replication, was undetectable and serum transaminases ALT and AST appeared normal. Analysis of pre-C mutant did not show mutation because the viral replication was inexistent for $\mathrm{HBe} \mathrm{Ag}$ negative women.

The comparison between HBs Ag-positive and HBs Ag-negative women did not show any significant difference for exposure factors studied.

We calculated the odds ratio to evaluate the impact of history of surgery and transfusion as well as that of tattoos and scarifications. Among the HBs Ag-positive patients, any of them did not carried HBe $\mathrm{Ag}$ which is associated with a high risk of perinatal transmission of the HBV. Indeed, it has been reported that newborns of simultaneously $\mathrm{HBs} \mathrm{Ag}$ and $\mathrm{HBe} \mathrm{Ag}$-positive mothers at the same time will have a chance of the perinatal acquisition of the infection by the HBV of $70 \%-90 \%$ [15].

These results, along with others, enable exploring the transmission risk perinatal of the $\mathrm{HBV}$ on the basis of the estimate prevalence of $\mathrm{HBe} \mathrm{Ag}$ in all the areas of the world. Those revealed that in 2005, more than $22.7 \%$ to $29.9 \%$ of the HBs Ag-positive women in age to procreate in sub-Saharan Africa and Central 
Africa were HBe Ag-positive [16].

The low viral loads going from undetectable to 202 copies $/ \mathrm{ml}$ showed that the hepatitis was inactive. However, assessment of viral load at the end of the pregnancy should be performed in slightly viremic women since it was described a possible increase of the maternal viremia of a factor of up to $1 \log$ in $\mathrm{HBe}$ Ag-women [17].

These HBs Ag positive women, although carrying inactive hepatitis, remain contagious.

In seronegative women, previous vaccination against the $\mathrm{HBV}$ was reported in only $10.9 \%$ of the cases. The high family antecedents of hepatitis B in HBs Ag-positive women (14.2\%) is consistent with previous work reporting acquisition of the disease before 20 years of age, suggesting an intrafamily horizontal transmission or inter-children in childhood and adolescence.

The intrafamily transmission from a young age seems to be an important mode of contamination in our country and an early screening of the infection among women would allow protection by vaccination of the partners and all the people living under the same roof.

\section{Conclusion}

In light of our results, it would be reasonable to promote vaccination before the pregnancy and to make a systematic screening of HBs Ag. Beyond vaccination of newborns from $\mathrm{HBs}$ Ag positive mothers, it is important to measure the viral load of $\mathrm{HBs} \mathrm{Ag}$ positive and $\mathrm{HBe} \mathrm{Ag}$ negative women to monitor the perinatal transmission risk and to prevent HBV by a neonatal seroprophylaxis. Advices on prevention of HBV transmission should also be provided to pregnant women positive for $\mathrm{HBs} \mathrm{Ag}$.

\section{References}

[1] OMS, Hépatite, B, Factsheet Update, WHO (2017). http://www.who.int/mediacentre/factsheets/fs204/fr/

[2] Sogni, P. (2015) Grossesse et hépatites virales B et C. La Presse Médicale, 44, 654659. https://doi.org/10.1016/j.lpm.2015.04.018

[3] Bacq, Y. (2008) Hépatite virale B et Grossesse. Gastroentérologie Clinique et Biologique, 32, S12-S19. https://doi.org/10.1016/s0399-8320(08)73260-3

[4] Sall Diallo, A., Sarr, M., Fall, Y., Diagne, C. and Kane, M.O. (2004) Etude de l'infection par le virus de l'hépatite virale B dans la population infantile au Sénégal. Dakar Medical, 49, 136-142.

[5] Diop, M., Diouf, A., Seck, S.M., Lo, G., Daye, K., Massaly, A., Dieye, A., Fall, N.M., Cisse-Diallo, V.M.P., Diallo-Mbaye, K., Lakhe, N.A., Fortes-Deguenovo, L., Ndour, C.T., Soumare, M. and Seydi, M. (2017) Prévalence de l'antigène de surface du virus de l'hépatite $\mathrm{B}$ et facteurs associés chez des militaires sénégalais envoyés en mission au Darfour. The Pan African Medical Journal, 26, 154. https://doi.org/10.11604/pamj.2017.26.154.11594

[6] Braillon, A., Nguyen-Khac, E., Merlin, J., Dubois, D., Gondry, J. and Capron, D. (2010) HBs Ag Screening during Pregnancy in the French Province Picardy. 
Gynécologie Obstétrique et Fertilité, 38, 13-17. https://doi.org/10.1016/j.gyobfe.2009.11.002

[7] Araz, N.C. and Dikensoy, E. (2011) Seroprevalence of Hepatitis B among Pregnant Women in Southern Turkey. The Journal of Pakistan Medical Association, 61, 176177.

[8] Coursaget, P., Gharbi, Y., Khrouf, N., Depril, N., Boukhris, N., Fritzell, B. and Kastally, R. (1994) Familial Clustering of Hepatitis B Virus Infections and Prevention of Perinatal Transmission by Immunization with a Reduced Number of Doses in an Area. Vaccine, 12, 275-278. https://doi.org/10.1016/0264-410X(94)90205-4

[9] Soltani, M.S., Bchir, A., Slimane, M.N., Mtiraoui, A., Ghanem, H., Hammami, M., El May, M., Gueddiche, M.N., Ben Ammar, R. and Sidhom, M. (1994) MotherChild Transmission of Hepatitis B Virus in the Tunisian Sahel. Revue dépidémiologie Santé Publique, 42, 529-532.

[10] Hannachi, N., Bahri, O., Mhalla, S., Marzouk, M., Sadraoui, A., Belguith, A.,Triki, H. and Boukadida, J. (2009) Hépatite virale B chez les femmes enceintes tunisiennes: Facteurs de risque et intérêt de l'étude de la réplication virale en cas d'antigène HBe négatif. Pathologie Biologie, 57, e43-e47. https://doi.org/10.1016/j.patbio.2008.04.017

[11] Bigot, K.A., Kodjoh, N., Zohoun, I.S., Hountondji, A., Latoundji, S., Takpara, I., De Souza, J., Aboudou, S., Alihonou, E. and Aguessy-Anhy, B. (1992) Séroprévalence de l'antigène $\mathrm{HBs}$ du virus de l'hépatite $\mathrm{B}$ chez les femmes enceintes et leurs enfants. Médecine d Afrique Noire, 39, 487-490.

[12] Sidibé, S., Sacko, Y. and Traoré, I. (2001) Prévalence des marqueurs sérologiques du virus de l'hépatite $\mathrm{B}$ chez les femmes enceintes dans le district de Bamako, Mali. Bulletin de la Société de Pathologie Exotique, 94, 339-341.

[13] Roingeard, P., Diouf, A., Sankale, J.L., Boye, C., Mboup, S., Diadhiou, F. and Essex, M. (1993) Perinatal Transmission of Hepatitis B Virus in Senegal, West Africa. Viral Immunology, 6, 65-73. https://doi.org/10.1089/vim.1993.6.65

[14] Lo, G., Diawara, P.S., Diouf, N.N., Faye, B., Seck, M.C., Sow, K., Sarre, S.M., Ndiaye, H.D., Toure Kane, N.C. and Mboup, S. (2012) Prévalence de l'antigène de surface $\mathrm{du}$ virus de l'hépatite $\mathrm{B}$ (AgHBs) chez les femmes enceintes au laboratoire de l'hôpital Militaire de Ouakam (HMO), Dakar. Médecine d'Afrique Noire, 59, 241 244.

[15] McMahon, B.J., Heyward, W.L., Templin, D.W., Clement, D. and Lanier, A.P. (1989) Hepatitis B-Associated Polyarteritisnodosa in Alaskan Eskimos: Clinical and Epidemiologic Features and Long-Term Follow-Up. Hepatology, 9, 97-101. https://doi.org/10.1002/hep.1840090116

[16] Ott, J.J., Stevens, G.A., Groeger, J. and Wiersma, S.T. (2012) Global Epidemiology of Hepatitis B Virus Infection: New Estimates of Age-Specific HBsAg Seroprevalence and Endemicity. Vaccine, 30, 2212-2219. https://doi.org/10.1016/j.vaccine.2011.12.116

[17] Söderström, A., Norkrans, G. and Lindh, M. (2003) Hepatitis B Virus DNA during Pregnancy and Post Partum: Aspects on Vertical Transmission. Scandinavian Journal of Infectious Diseases, 35, 814-819. https://doi.org/10.1080/00365540310016547 
Submit or recommend next manuscript to SCIRP and we will provide best service for you:

Accepting pre-submission inquiries through Email, Facebook, LinkedIn, Twitter, etc. A wide selection of journals (inclusive of 9 subjects, more than 200 journals)

Providing 24-hour high-quality service

User-friendly online submission system

Fair and swift peer-review system

Efficient typesetting and proofreading procedure

Display of the result of downloads and visits, as well as the number of cited articles Maximum dissemination of your research work

Submit your manuscript at: http://papersubmission.scirp.org/

Or contact oji@scirp.org 